\title{
USE OF DUMP ROCKS IN BACKFILL MIXTURES WHILE MINING IRON-ORE DEPOSITS
}

\author{
Petlovanyi M. V., Ganushevych K. A.
}

\section{INTRODUCTION}

In most developing countries, where the industrial type of economy prevails, the intensive functioning of the industrial sector is followed by a high rate of waste production. It happens for a number of reasons: the use of low-tech equipment and mechanisms, physical and moral deterioration of equipment over time, imperfection of the legal framework in the field of state regulation of waste management and the principles of markets formation for waste utilisation in various sectors.

Significant amounts of waste at the low level of its utilization leads to negative consequences in the ecological, economic and social spheres, namely pollution of environmental components (soils, groundwater and surface waters), alienation of large areas of valuable land, payment of enterprises for waste disposal, creation of depressive man-caused landscapes in mining regions and a number of other consequences ${ }^{1,2,3,4}$.

Ukraine is also among the countries with high level of waste formation. According to the statistical date of 2018, 346.7 million tons of I-IV hazard class waste were created or about 11 tons per citizen. The largest contribution to the total waste production of the country is made

${ }^{1}$ Hrinov, V.H., Khorolskyi, A.O.., \& Kaliushhenko, O.P. (2019). Elaboration of environmental scenarios for the effective development of valuable mineral deposits. Mineral resources of Ukraine, (2), 46-50. https://doi.org/10.31996/mru.2019.2.46-5

2 Pavlychenko, A., Buchavyy, Y., Fedotov, V., \& Rudchenko, A. (2017). Development of methodological approaches to environmental evaluation of the influence of manmade massifs on the environmental objects. Technology Audit and Production Reserves, 4(3(36)), 22-26. https://doi.org/10.15587/23128372.2017.109243

3 Popovych, V., Kuzmenko, O., Voloshchyshyn, A., \& Petlovanyi, M. (2018). Influence of man-made edaphotopes of the spoil heap on biota. E3S Web of Conferences, (60), 00010. https://doi.org/10.1051/e3sconf/20186000010

${ }^{4}$ Pinder, V.F., \& Popovych, V.V. (2017). Reclamation of mine rock dumps of liquidates mines in Lviv-Volyn coal basin. Scientific Bulletin of UNFU, 27(3), 113-116. https://doi.org/10.15421/40270325 
by the mining industry with a rate of 301 million tons, or $86.9 \%$ (Fig. 1) ${ }^{5,6}$.

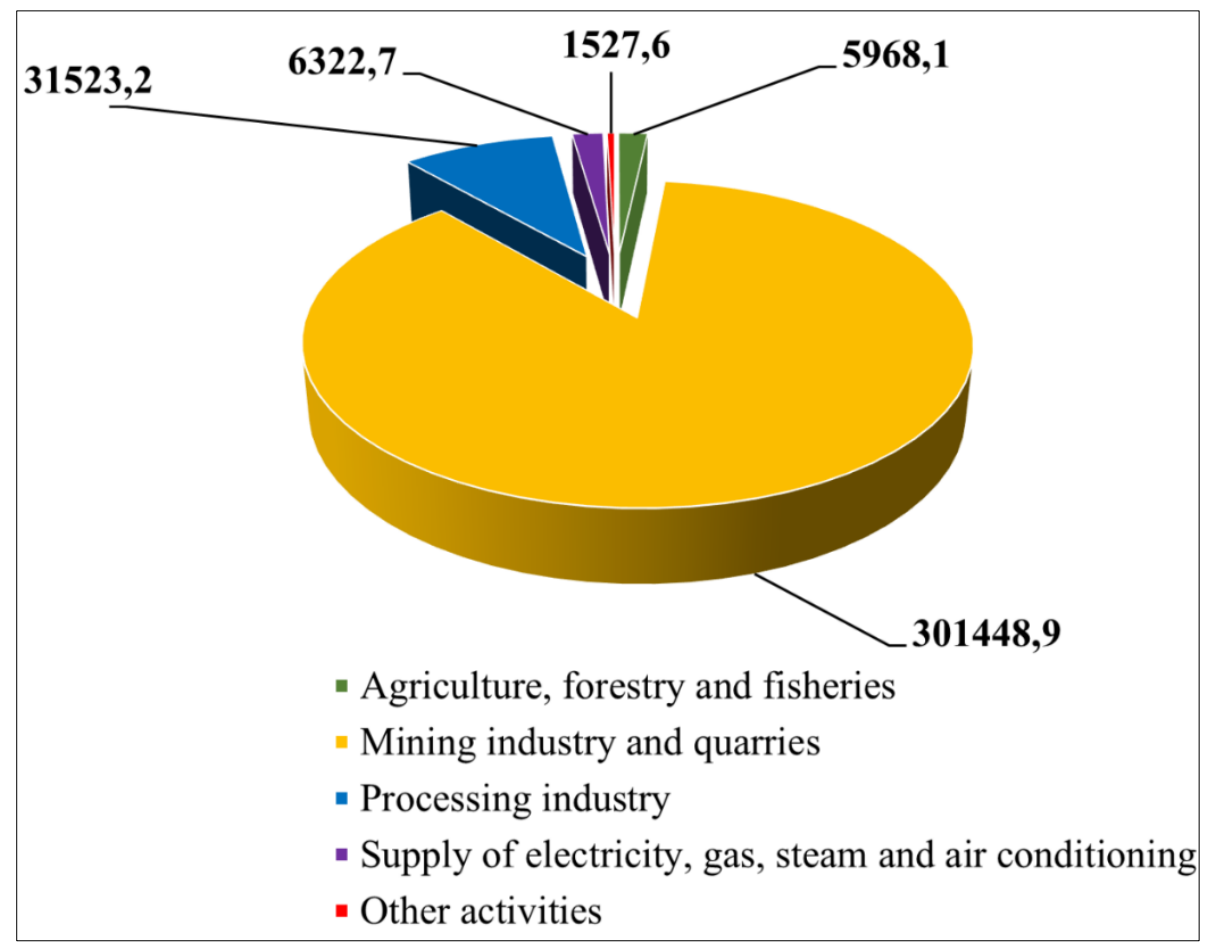

Fig. 1. Distribution of the amount of waste generated in 2019 by economic type of activity (thous. tons)

Analysis of the figure points out that the only way to significantly reduce the level of waste generation is to develop measures for maximum waste disposal in the mining industry.

According to detailed statistical information on the production of mining waste, the largest amount of waste falls on the extraction of metal ores, namely iron ore. This is due to the storage on the surface of overburden, empty quarry and mine rocks during mining; tailings and sludges of enrichment in dumps and storages - in the process of technological cycle of enrichment. Wastes from iron ore mining and processing have a density of 1.5-2 times higher than, for example, mining of coal or other minerals, so the total tonnage is much higher.

5 Статистичний збірник “Довкілля Украӥни” за 2018 рік. (2019). Київ, Україна: Державна служба статистики України, 214 с.

${ }^{6}$ Petlovanyi, M., Kuzmenko, O., Lozynskyi, V., Popovych, V., \& Sai, K. (2019). Review of man-made mineral formations accumulation and prospects of their developing in mining industrial regions in Ukraine. Mining of Mineral Deposits, 13(1), 24-38. https:// doi.org/10.33271/mining13.01.024 


\section{Formulation of the problem}

Today's level of mining waste utilization is at the level of $25-30 \%$ and consists in backfilling of deformed earth surfaces disturbed by mining operations, beams, ravines or partial use in civil or road construction. The existing amount of utilization is not enough, because the total amount of mining waste generated is much higher than the volume of utilization, so it is predicted that they will constantly accumulate and be stored on the surface.

If in opencast mining part of the overburden and empty quarry rocks can mostly be disposed of in restoration works after working off the reserves, then in the underground it is possible to dispose of industrial mining waste in the underground worked-out space during the deposit mining. In the case of valuable ore reserves in the subsoil, the advanced development systems with the backfill of the worked-out space are used, that allows protecting the surface from deformation, reducing stress in the host rocks, creating safety of mining operations during extraction and disposing of industrial waste into the underground space s, $, 8,9,10^{\text {. }}$

Due to the fact that backfill operations significantly increase the cost of production, research is constantly conducted to improve the component composition of backfill mixtures based on industrial waste from local raw materials bases, where the mining company operates. To reduce the cost of backfill works, as a part of backfill mixtures, mine dump waste rocks from mining operations are used as a part of the combined inert filler $^{11,12,13,14}$, but in reality their amount does not exceed $20-30 \%$. In the

7 Chistyakov, E., Ruskih, V., \& Zubko, S. (2012). Investigation of the geomechanical processes while mining thick ore deposits by room systems with backfill of worked-out area. Geomechanical Processes During Underground Mining Proceedings of the School of Underground Mining, 127-132. https://doi.org/ 10.1201/b13157-23

${ }^{8}$ Кузьменко, А.М., \& Петлёваный, М.В. (2014). Влияние структуры горного массива и порядка отработки камерных запасов на разубоживание руды. Геотехнічна механіка, (118), 37-45.

${ }^{9}$ Kuzmenko, O.M., \& Petlovanyj, M.V. (2017). Steadiness of artificial massif during underground mining of thick ore deposit on a deep depth. Collection of Research Papers of National Mining University, (50), 56-62.

${ }^{10}$ Khorolskyi, A., Hrinov, V., \& Kaliushenko, O. (2019). Network models for searching for optimal economic and environmental strategies for field development. Procedia Environmental Science, Engineering and Management, 6(3), 463-471.

${ }^{11}$ Wu, J., Feng, M., Mao, KH., KHu, J., Zhang, W., Ni, KH., \& Han, G. (2018). Particle size distribution of aggregate effects on mechanical and structural properties of cemented rockfill: Experiments and modeling. Construction and Building Materials, (193), 295-311 https://doi.org/10.1016/j.conbuildmat.2018.10.208 
case of increasing the amount of rock utilization in the backfill mixture, the level of its utilisation also increases.

In Ukraine the progressive mining methods with backfilling using solidifying mixtures are used only in two mines - PJSC "Zaporizhzhia Iron Ore Plant" (iron ore mining) and State Enterprise "EastMPP Mining and Processing Plant" (uranium ores mining). These enterprises use waste mine rocks as part of backfill mixtures but this is not enough for the general problem of utilization of accumulated rocks of the mining industry. There are 8 iron ore mines in Kryvbas, but their mining technology does not involve backfilling of the worked-out space, although the mineral resource base of potential backfill materials is significant $^{15,16,17}$.

Thus, scientific and technical substantiation and search for ways to intensify the use of mine waste as a backfill material, which are stored in surface waste heaps, both for the working conditions of mines working with backfill, and those where backfill can be implemented in the future is a relevant question. Intensification of the use of mine waste will eventually reduce their negative impact on the environment, in some cases may lead to the gradual elimination of the rock dump and reduce the payment of environmental tax for waste disposal.

${ }^{12}$ Lingga, B.A., \& Apel, D.B. (2018). Shear properties of cemented rockfills. Journal of Rock Mechanics and Geotechnical Engineering, 10(4), 635-644. https://doi.org/10.1016/j.jrmge.2018.03.005

${ }^{13}$ Мельник, П.Е. \& Хрисанов В.В. (2010). Использование шахтных пород и отходов углеобогащения в качестве закладочного материала при подземной угледобыче. Горный Информационно-Аналитический Бюллетень, (5), 282-287.

${ }^{14}$ Крупник, Л.А., Битимбаев, М.Ж., Шапошник, С.Н, Шапошник, Ю.Н, \& Демин, В.Ф. (2015). Обоснование рациональной технологии закладочных работ на месторождении Секисовское. Физико-Технические Проблемы Разработки Полезных Ископаемых, (3), 82-90.

${ }^{15}$ Bazaluk, O., Petlovanyi, M., Lozynskyi, V., Zubko, S., Sai, K., \& Saik, P. (2021). Sustainable underground iron ore mining in ukraine with backfilling worked-out area. Sustainability, 13(2), 834. https://doi.org/10.3390/su13020834

${ }^{16}$ Khomenko, O., Kononenko, M., Myronova, I., \& Yurchenko, K. (2017). Ways of technogenic loading decreasing on mining regions of Ukraine. Collection of Research Papers of National Mining University, (51), 77-83.

${ }^{17}$ Кузьменко, А.М., \& Петлёваный, М.В. (2014). Состояние и перспективы развития закладочных работ на подземных рудниках Украины. Геотехнічна механіка, (110), 89-97. 


\section{Research methodology}

\subsection{Research of the chemical and mineralogical composition of dump mine rocks}

The method of infrared spectroscopy was used to study the peculiarities of the chemical and mineralogical composition. Infrared spectra of samples of dump rocks using SPECORD-75IR device. $0.5-3 \mathrm{mg}$ of finely ground material is enough to obtain the spectrum of the sample. Sampling of dump rocks was carried out in the wavelength range of $4200-400 \mathrm{~cm}^{-1}$. The obtained spectrograms were identified in accordance with the reference data on the intensity of the mineral at a certain wavelength ${ }^{18}$.

Studies of the microstructure, as well as the phase and quantitative composition of the components of the hardening backfill and artificial stone were performed using scanning electron microscopy ${ }^{19}$. Using the electron microscope-microanalyzer REMMA-102-02, it is possible to obtain high-quality photographs of the shapes of the structures of the studied samples at a magnification of $50 \mu \mathrm{m}$. The built-in X-ray spectral microanalyzer gives the chance to make measurements of chemical composition of structural formations of a hardening backfill.

\subsection{Laboratory studies for intensification of dump rocks usage in backfill mixture}

The research was carried out for the conditions of PJSC "Zaporizhzhia Iron Ore Plant", which mines iron ore reserves of the South Belozirsky deposit by a progressive pillar mining system with hardening backfill. As a part of inert filler 20-30\% of the crushed dump rocks are used.

To increase the proportion of rocks in the backfill mixture and prevent a decrease in the standard strength of the mortar array, an experimental laboratory program for testing the mortar mixture based on mechanically activated binder (blast furnace slag) by grinding its particles in a ball mill was developed ( $55 \%$ of particles of the $-0.074 \mathrm{~mm}$ class). The influence of mechanical activation of binders on the properties of backfill mixtures and its effectiveness has been sufficiently studied in the practice of backfill operations $^{20,21,22}$.

${ }^{18}$ Накамото, К. (1991). ИК спектры соединений. Москва, Россия: Мир, 536 с.

${ }^{19}$ Голдстейн, Д., Ньюбери, Д., \& Эчлин, П. (1984). Растровая электронная микроскопия ыл рентгеновский микроанализ. Москва, Россия: Мир, 303 с.

${ }^{20}$ Petlovanyi, M.V., Zubko, S.A., Popovych, V.V., \& Sai, K.S. (2020). Physicochemical mechanism of structure formation and strengthening in the backfill massif 
The study accepted the composition of the backfill mixture recommended by NDGRI (2001) for PJSC "Zaporizhzhia Iron Ore Plant": binding material - blast furnace granulated slag blast furnace granulated slag $-18 \%$, waste flux production $-47 \%$, crushed waste rock $-17 \%$, water $-18 \%$. The fineness of grinding slag for the experiment was taken in accordance with GOST 6613 and when sifting through a sieve \#008 must pass at least $85 \%$ by weight of the sample. Blast furnace granulated slag for the experiment was ground in a laboratory ball mill. The loading capacity of the mill is $1 \mathrm{~kg}$. After sieving the finished mass through a sieve \#008, 92\% of the particles have gone through. The process of grinding slag in ball mills to the required fineness is characterized by a decrease in productivity and increase in energy consumption. For the purpose of economic expediency, the compositions of the backfill mixtures were designed with $25 \%$ lower consumption of binding material $\left(300 \mathrm{~kg} / \mathrm{m}^{3}\right)$, while the reduced part was proportionally replaced by rock and flux.

The activity of blast furnace slag brought to a fine grinding of $92 \%$ of particles with a size of $0.074 \mathrm{~mm}$ was checked by preparing on its basis the backfill mixture. For this purpose in the laboratory of the backfill complex 4 experimental mixtures with the content of rock in the inert aggregate, respectively, 25, 30, 40, 50\% were prepared (Fig. 2). The particle size distribution was determined by sieve method. According to standard methods according to $^{23}$, the mobility of the mixture, the maximum shear stress of the mixture and the strength of uniaxial compression at the life-span of 90 days were determined.

when filling underground cavities. Voprosy Khimii i Khimicheskoi Technologii, (6), 142-150. https://doi.org/10.32434/0321-4095-2020-133-6-142-150

21 Petlovanyi, M., \& Mamaikin, O. (2019). Assessment of an expediency of binder material mechanical activation in cemented rockfill. ARPN Journal of Engineering and Applied Sciences, 14(20), 3492-3503.

22 Кузьменко, А.М., Петлёваный, М.В., \& Усатый, В.Ю. (2010). Влияние тонкоизмельченных фракций шлака на прочностные свойства твердеющей закладки. В Матеріалах Міжнародної науково-практичної конференції “Школа nідземної розробки” (с. 383-386). Дніпропетровськ, Україна: Національний гірничий університет.

${ }^{23}$ Кузьменко, А.М., Петлёваный, М.В., \& Усатый, В.Ю. (2010). Твердеющая закладка при отработке рудных крутых залежей в сложных горногеологических условиях. Днепропетровск, Украина: Национальный горный университет, 139 с. 


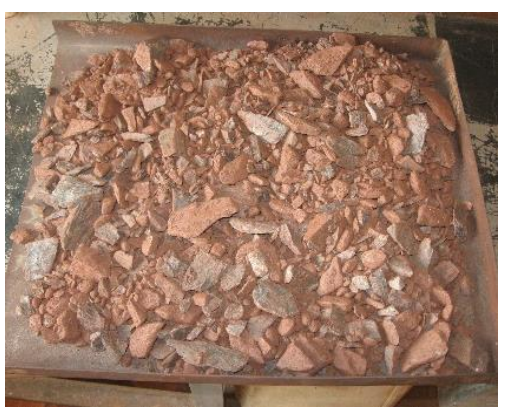

(a)

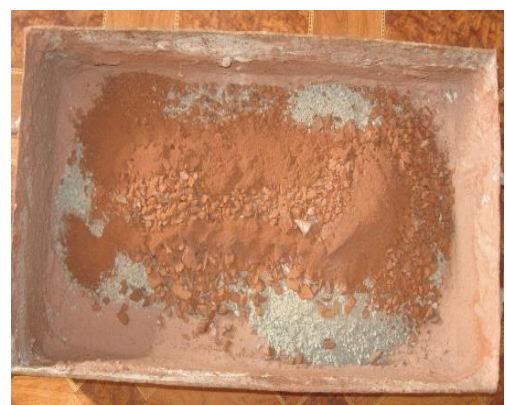

(b)

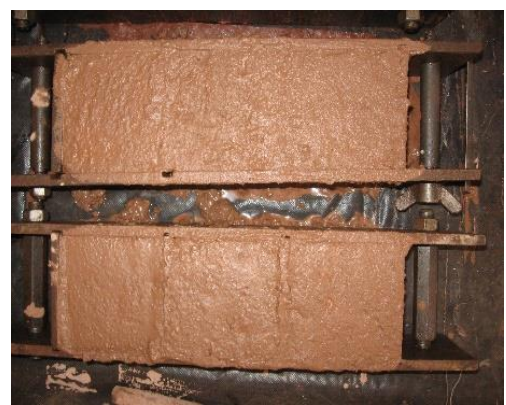

(c)

Fig. 2. Illustration of backfill mixture preparation methodical stages:

(a) selection and drying of rocks; (b) mixing the components of the mixture and adding water; (c) pouring samples of the mixture into molds and its hardening

An analysis of the parameters of the waste heap according to his passport was also performed. The balance of reception and utilization of waste heaps in the backfill mixture was analytically determined depending on their content and possible volumes of reduction or elimination of waste rock accumulations were estimated.

\section{Research results}

\subsection{Characteristics of dump rocks}

The pillar mining method of ore deposit mining using backfilling of the worked-out space by hardening mixtures is accepted as the technology of iron ores extraction. Annual production is 4.5 million tons of iron ore, and the volume of preparation of the backfill mixture is 1.0 million $\mathrm{m}^{3}$. As in all underground mines, as a result of mining operations there is some accumulated waste rock on the surface (Fig. 3).

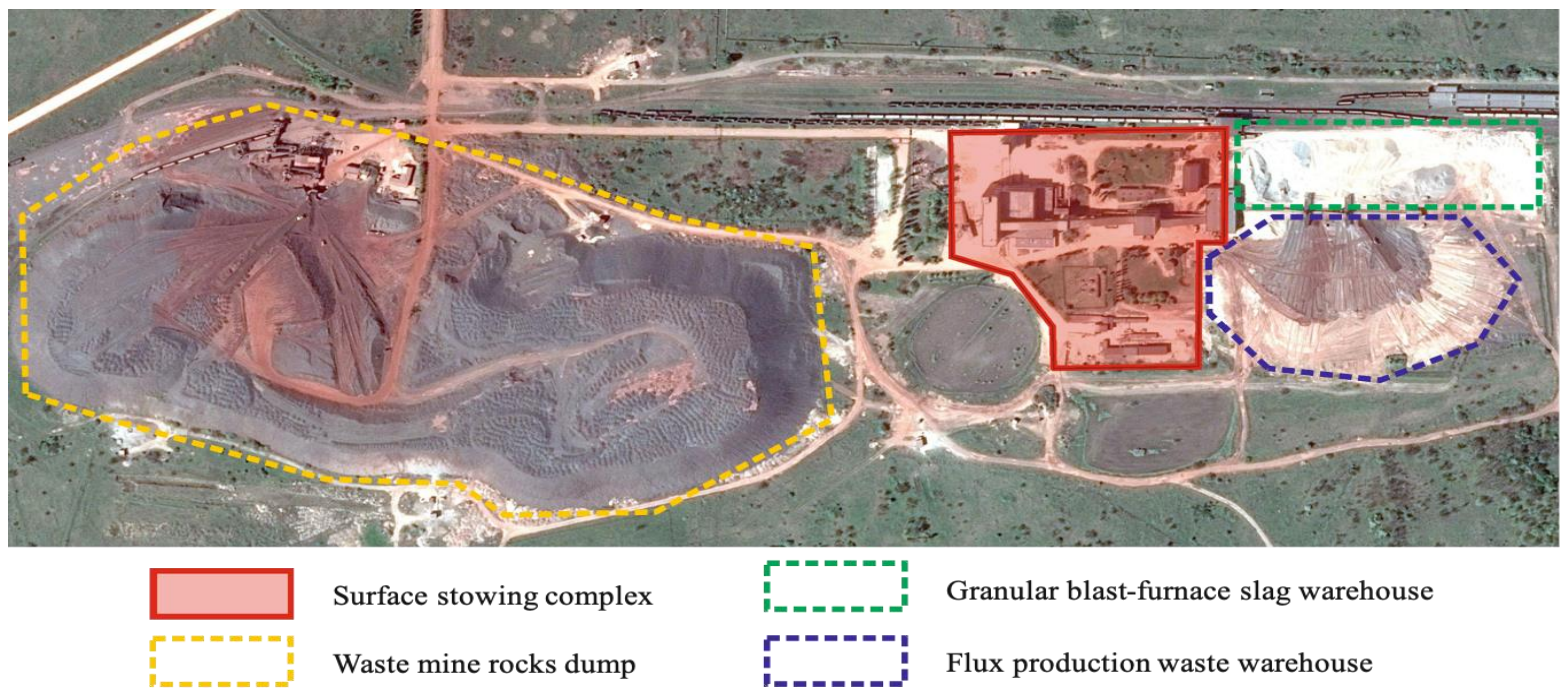

Fig. 3. Location of the waste rock dump near the backfill complex 
The waste dump is intended for storage of the rock mass received while driving mine workings along the rocks of foot and hanging walls of the ore deposit. The dump is located in the mine allocation of the plant above the central part of the ore body, and it has a rectangular shape of its boundaries. A vegetable soil (black soil) is left under the dump. Below are deposits in the form of loam with the presence of groundwater 5-8 $\mathrm{m}$ from the surface. Mine rocks mined in the mine are not toxic, so they do not have a detrimental effect on the underlying soils and aquifer. The average annual amount of rock entering the dump is about 500 thousand tons. At the initial stage of construction and operation of the plant from the dump up to 100 thousand tons of rocks for backfilling the foundations of roads and railways was used. To date, this figure is much lower. Flat single-tier bulldozer dump with delivery of rock by road is accepted. Part of the rock for the crushing and backfill complex is transported by rail. Fig. 4 shows full-scale photographs of the waste dump and buccal crusher - the main sources of dust pollution, and the parameters of the dump are in the Table 1.

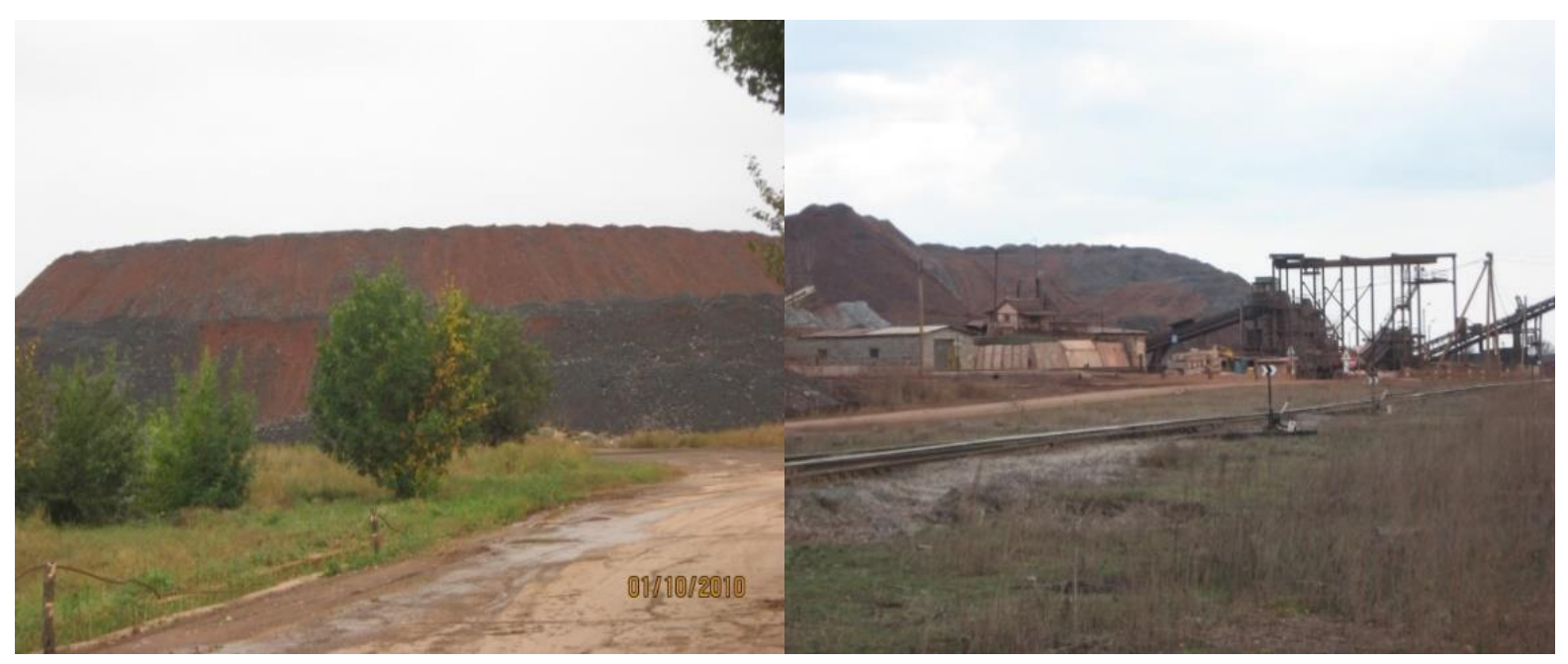

Fig. 4. Rock dump and rock crushing complex for backfill mixture

According to the geological service of PJSC "Zaporizhzhia Iron Ore Plant", the host rocks of the ore deposit in the subsoil are quartz-hematitesericite, medium-coarse-shale, folded, quartzized with vein quartz shales, with rare layers of quartzites, hematite fematite-hematite with strength coefficient being $-f=7-9$ sometimes $f=8-9$, fracture volume of the II-III orders, cracks are multidirectional, average stability. The average iron content in the host rocks is $20-30 \%$. The volume weight of shales is $2.6 \mathrm{t} / \mathrm{m}^{3}$. 
In the technological process of iron ore the dump rock is used as part of the inert backfill in the production of backfill operations.

Table 1

Rock dump parameters

\begin{tabular}{|c|c|}
\hline Parameter & Value \\
\hline Area, hectare & 14.8 \\
\hline Length, $\mathrm{m}$ & 550 \\
\hline Width, $\mathrm{m}$ & 275 \\
\hline Height, $\mathrm{m}$ & 20 \\
\hline $\begin{array}{c}\text { Amount of stored rocks, mln. t. } \\
\text { molume of rocks going to the dump, } \\
\text { mlyear }\end{array}$ & 0.55 \\
\hline $\begin{array}{c}\text { Amount of rocks usage in the backfill, } \\
\text { mln. t/year }\end{array}$ & $\begin{array}{c}\text { Depends on the backfill } \\
\text { mixture composition }\end{array}$ \\
\hline
\end{tabular}

In 2001, the employees of the plant together with the staff of NDGRI (Kryvyi Rih) proposed to use $25-30 \%$ of the amount of inert filler the mine waste rocks accumulated in the dump from the drivage of mine workings, pre-crushed to a certain particle size distribution. Thus, in the long run it was expected to reduce the volume of the dump, and, consequently, the mass of dust emissions from its surface. After these changes, the component composition of the backfill mixture has the following look: binder - blast furnace granulated slag, inert fill - flux dolomite, dump rock and water. The inert filler as a result of the addition of rocks has become combined.

\subsection{Chemical and mineralogical composition of dump rocks}

By applying the method of infrared spectroscopy, a spectrogram of samples of dump rocks was obtained, which are used as a component of the backfill mixture, which are presented in Fig. 5. Preliminary mineralogical composition was available for rock identification. The rocks concentrated in the dump are represented mainly by quartz-chloritesericite shales, and accordingly the minerals and minerals of their morphological group are most likely present in the dump rocks.

The analysis of the Fig. 5 shows that in the rock there is hematite with weak absorption bands $450-470,530 \mathrm{~cm}^{-1}$, muscovite with absorption bands 475-540; 750; 820; 920; 1030-1080; 3622 $\mathrm{cm}^{-1}$; biotite 460; 620; $700 ; 1010 ; 1620 ; 3650 \mathrm{~cm}^{-1}$; chlorite $450 ; 670 ; 1010 ; 1450 ; 3600 \mathrm{~cm}^{-1}$. 
The appearance of a number of peaks in the wavelength range of $3600 \mathrm{~cm}^{-1}$ indicates the presence of water of crystallization in the structure of biotite, muscovite, chlorite.

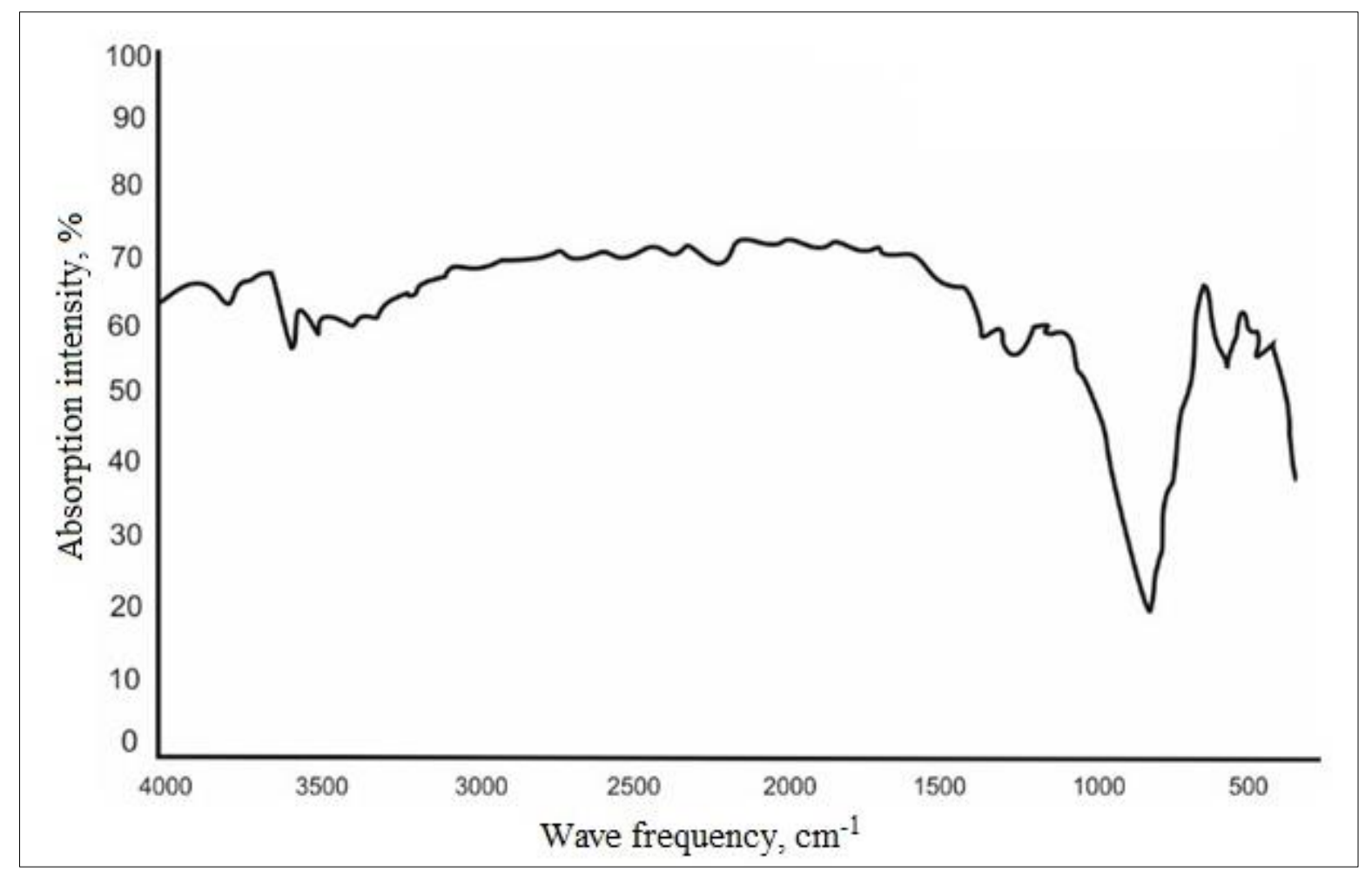

Fig. 5. Infrared spectrograms of dump rocks

Samples of dump rocks were also examined by scanning electron microscopy, which is presented in Fig. 6. Using a built-in micro-X-ray spectrum analyzer, the chemical composition of the detected minerals of different morphological characteristics (color) was determined on the obtained photographs. Data on measurements of the chemical composition are summarized in Table 2.

Analyzing the data in the table, it can be stated that the predominant minerals in the rocks are hematite, biotite, chlorite, muscovite, sericite, as well as minerals of the hydromica class. In terms of physicochemical properties, the discovered minerals of dump rocks are inert, do not have astringent properties and form a rigid base in the hardened mortar, absorbing heat during hydration of the binder.

The valuable content of hematite in the composition of waste rocks draws attention as a valuable mineral resource, the extraction of which can be of important commercial importance. 


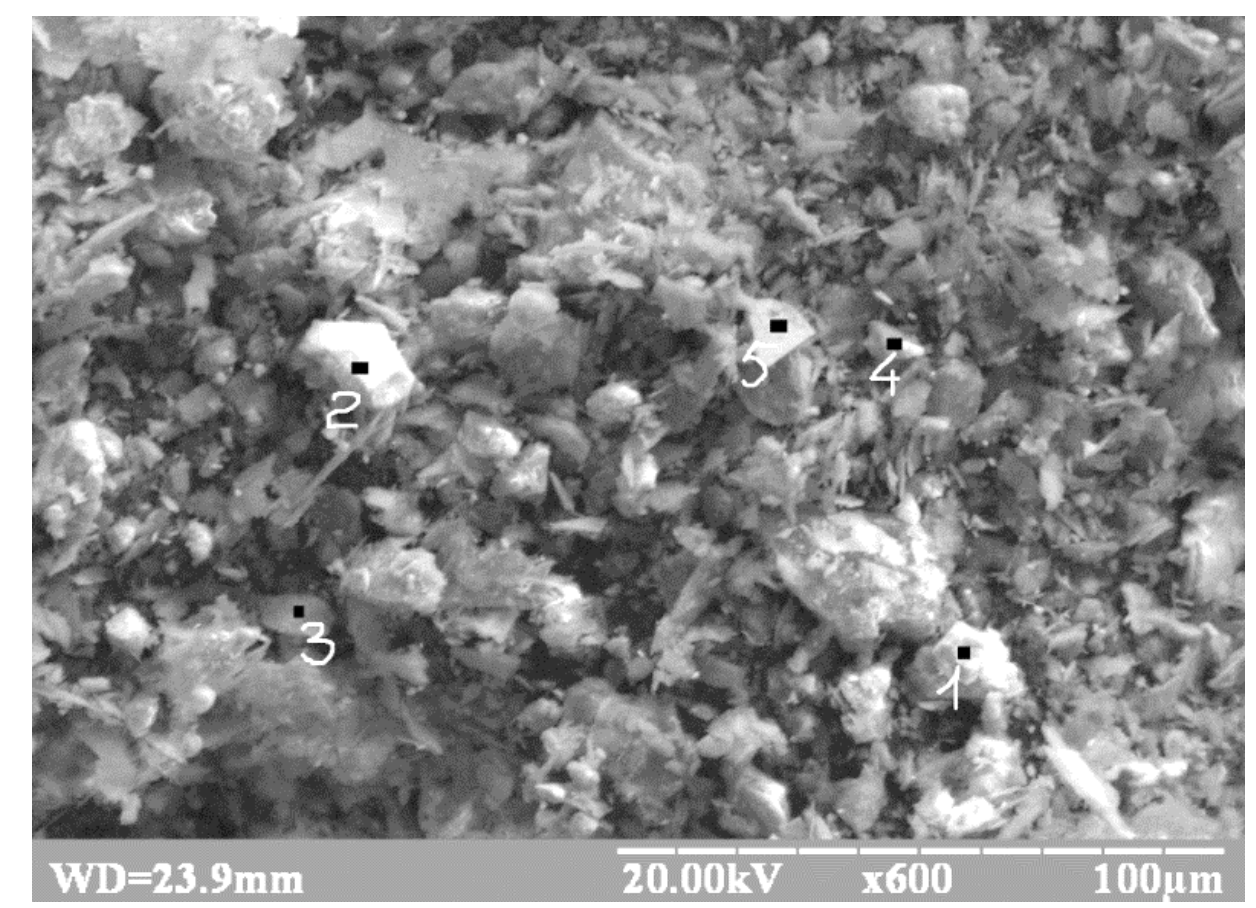

Fig. 6. Microphotographies of the particles of dump rock:

$1,2,3,4,5$ - points of chemical composition measurements

Table 2

The results of micro-X-ray spectral analysis of the composition of dump rocks

\begin{tabular}{|c|c|c|c|c|c|c|c|c|}
\hline \multirow{2}{*}{ Sample } & \multirow{2}{*}{$\begin{array}{l}\text { Sample } \\
\text { number }\end{array}$} & \multicolumn{6}{|c|}{ Basic oxides content, $\%$} & \multirow{2}{*}{ Mineral } \\
\hline & & $\mathrm{CaO}$ & $\mathrm{Al}_{2} \mathrm{O}_{3}$ & $\mathrm{MgO}$ & $\mathrm{SiO}_{2}$ & $\mathrm{Fe}_{2} \mathrm{O}_{3}$ & $\mathrm{~K}_{2} \mathrm{O}$ & \\
\hline \multirow{5}{*}{$\begin{array}{l}\text { Dump } \\
\text { rock }\end{array}$} & 1 & 0.85 & 2.25 & 0.87 & 3.28 & 88.0 & 1.21 & Hematite \\
\hline & 2 & 1.52 & 23.96 & 2.67 & 33.64 & 25.34 & 6.06 & Biotite \\
\hline & 3 & 0.96 & 19.87 & 7.53 & 29.46 & 33.16 & 1.91 & Chrolite \\
\hline & 4 & 0.73 & 6.14 & 23.64 & 56.71 & 6.19 & 1.40 & \multirow{2}{*}{$\begin{array}{l}\text { Mus- } \\
\text { covite }\end{array}$} \\
\hline & 5 & 0.70 & 27.53 & 2.34 & 52.04 & 8.81 & 4.92 & \\
\hline
\end{tabular}

\subsection{The results of laboratory studies of embedded mixtures with different rock content}

In laboratory conditions, compositions with high rock content were created and their properties were determined. Mine rocks were crushed to a size of $-20 \mathrm{~mm}$. Sieve analysis determined their particle size distribution: $+20 \mathrm{~mm}-3.2 \%,-20 \ldots+10 \mathrm{~mm}-44.1 \%,-10 \ldots+5.0 \mathrm{~mm}-$ $27.3 \%,-5.0 \ldots+2.5 \mathrm{~mm}-9.5 \%,-2.5 \ldots+1.25 \mathrm{~mm}-2.9 \%,-1.25 \mathrm{~mm}-$ $13.3 \%$. The parameters of backfill mixtures with increased rock consumption were determined: mobility - are in the range of $11.0-11.5 \mathrm{~cm}$ and 
maximum stress shear $-9 \ldots-14 \mathrm{kgf} / \mathrm{m}^{2}$. These parameters satisfy the conditions of pipeline transport of the backfill mixture. After 90 days of storage, the compositions were tested for strength. The compositions and test results of the backfill strength are given in Table 3.

Table 3

Experimental compositions of the backfill mixture with increased rock content

\begin{tabular}{|c|c|c|c|c|c|}
\hline \multirow{3}{*}{$\begin{array}{l}\text { Number } \\
\text { of storage }\end{array}$} & \multicolumn{4}{|c|}{ Components consumption for $1 \mathrm{~m}^{3}$ of backfill, $\%$} & \multirow{3}{*}{$\begin{array}{c}\text { Backfill } \\
\text { strength, } \\
\mathrm{MPa} \\
90 \text { days }\end{array}$} \\
\hline & \multirow{2}{*}{$\begin{array}{c}\text { Binding } \\
\text { Slag }\end{array}$} & \multicolumn{2}{|c|}{ Inert filler } & \multirow{2}{*}{ Water } & \\
\hline & & Flux & Rock & & \\
\hline$\# 1$ & 15 & 48 & $\begin{array}{c}17 \\
\text { (25\% of inert filler) }\end{array}$ & 20 & 8.9 \\
\hline$\# 2$ & 15 & 45 & $\begin{array}{c}20 \\
\text { (30\% of inert filler) }\end{array}$ & 20 & 8.65 \\
\hline \#3 & 15 & 39 & $\begin{array}{c}26 \\
\text { (40\% of inert filler) }\end{array}$ & 20 & 7.7 \\
\hline \#4 & 15 & 32.5 & $\begin{array}{c}32,5 \\
\text { (50\% of inert filler) }\end{array}$ & 20 & 7.1 \\
\hline
\end{tabular}

The presence of a certain number of large-scale mine rocks in the backfill mixture has a positive effect on the strength characteristics of the backfilled massif, increasing it by $10-25 \%$. But too much of them in the backfill mixture can lead to a decrease in strength, because the crystalline hydration products are not able to bind only large pieces of the filler, so it is necessary to have a sufficient amount of inert filler fraction of $0-10 \mathrm{~mm}$. Rational range is established by varying the content of the rock according to the strength of the backfill.

Generalization of the results of table 2 allowed to establish the degree dependence of the change in the strength of the backfilled massif on the volume of mine waste in the combined inert filler of the backfill mixture (Fig. 7).

The graph in Fig. 7 shows that with increasing the proportion of rock in the inert filler of the backfill mixture from 25 to $50 \%$, the strength of the backfill decreases. In our opinion, the most rational interval for adding dump rock to the inert filler is $40-50 \%$, at which the strength does not exceed the value of the standard strength. With a larger proportion of rock, the strength of the backfilled massif may decrease. To do this, in the laboratory it is necessary to prepare a number of compositions with a rock 
content of more than $50 \%$ and the results of strength indicators to establish a rational rock content.

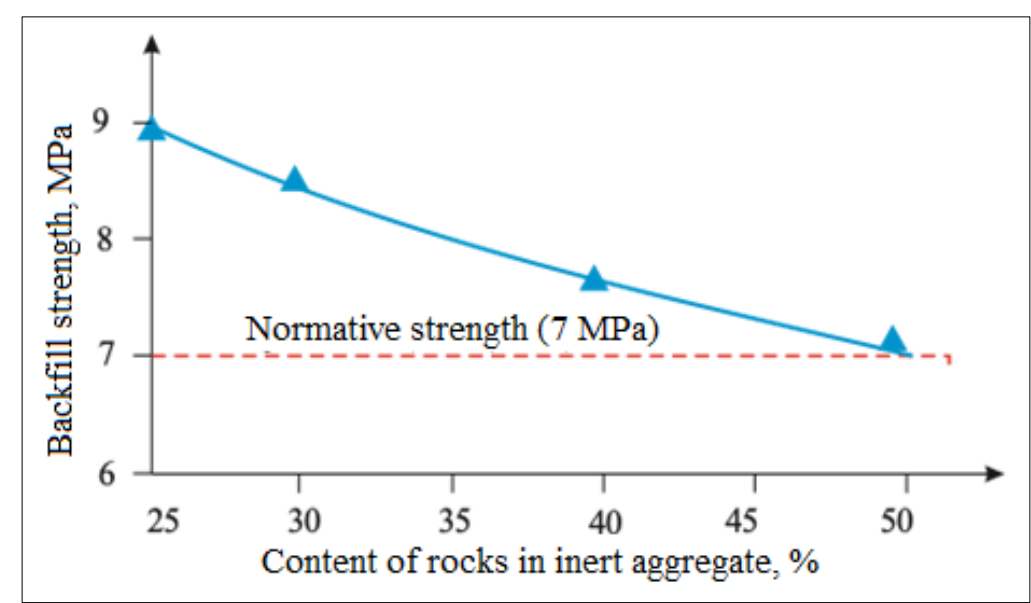

Fig. 7. Dependence of change in the strength of the backfilled massif on the content of rocks under the influence of fine binding material

There are several ways to achieve the dispersion of the domain of granular slag at the level of $92 \%-0.08 \mathrm{~mm}$. First, the composition of the backfill mixture is proposed to reduce by $25 \%$ the consumption of blast furnace slag, so you can increase the fineness of grinding in ball mills MSC $36 \times 55$ used in the backfill complex and slightly reduce the productivity of the final product at the outlet of the mill $\left(\mathrm{kg} / \mathrm{m}^{3}\right)$ because a smaller amount of slag is subject to grinding. Additional research is needed, but it may well be justified to economically increase the dispersion of the slag and, accordingly, energy consumption for grinding while reducing its costs by $25 \%$ in the backfill mixture. Secondly, it is possible to consider options for replacing the grinding unit with new models of mills, which are characterized by energy efficiency during grinding and which will pay off in a satisfactory time.

\subsection{Research of reception and utilization balance in a backfill of waste dump rocks}

If the annual volume of dump rock used for backfill operations exceeds the annual volume of rock coming from the drifting faces into the dump, this difference is a factor in reducing the volume of the dump over time. Annually, about $2.5 \%$ of the inflow of rock to the dump is used for backfilling the base of roads and railways and other purposes. The number of waste rocks in the dump is about 4.8 million tons as of 2018. Due to the increase in the volume of rocks in the backfill mixture can reduce the time 
of dump analysis and reduce its dust impact on the environment. The increase in the proportion of dump rock in the backfill mixture is possible due to the finer grinding of blast furnace granulated slag to increase its binding properties or by introducing special additives into the backfill mixture that increase the strength of the monolithic massif.

At certain rates of rock utilization, the time of dumping can be determined by calculating the following formula:

$$
T_{p}=\frac{Q_{o}}{\left(\Delta q+q^{\prime}\right)}, \text { years, }
$$

where

$T_{p}$ - time of dump stripping, years; $Q_{o}$ - amount of rocks in the dump, thous. t.;

$\Delta q$-difference between rock amount used for backfill and that are transported from drifting face to the dump, thous. $t$ /year;

$q^{\prime}$ - amount of rocks used for other purposes, thous. t/year.

According to the above-mentioned formula, it is possible to calculate the time of dump removal with increasing proportion of rock in the backfill. If you increase the content of rock in the backfill mixture, the volume of utilized waste rocks will increase accordingly and their inflow to the dump will be reduced, which will lead to its gradual elimination. The relationship between the change in the flow of rocks into the dump from the amount of rock in the inert filler is presented in Fig. 8.

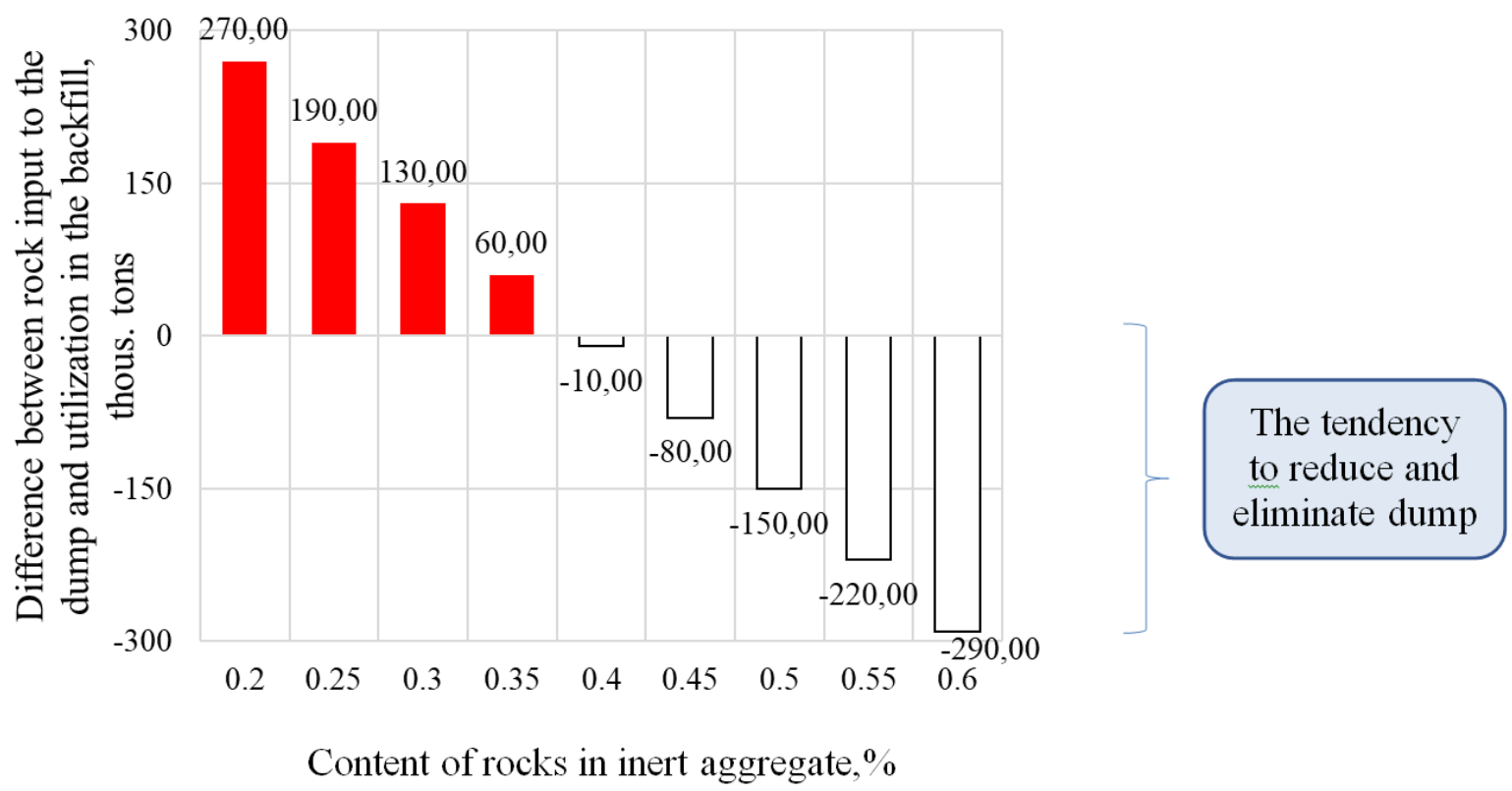

Fig. 8. Balance of the flow and utilization of waste rocks in the backfill 
Analyzing the graph of Fig. 8 it is possible to observe that when the content of the backfill in an inert filler equals to $35 \%$ of mine dump rocks there will be an excess of rocks inflow over their utilization into the backfill, accordingly the dump will not be reduced in due course. When the content of rocks in the inert filler is more than $40 \%$ of the inflow of rocks this difference will gradually reduce the accumulation of rocks and eventually eliminate the dump. So, at the recommended level of utilization of rocks in the filler of $50 \%$ the time of the dump removal will take 32 years. If we take into account that the service life of the plant will be about 30 years, then before the mine closes the waste dump will be completely removed. If to improve the composition of the backfill mixture and bring the content of rocks to $60 \%$ - the removal time will make 16.5 years.

When using $50 \%$ of rocks in the inert filler of the backfill mixture, the amount of dust generated during dumping per year will be reduced by $70 \%$ (up to $100 \mathrm{t} /$ year), as the greatest dusting is observed during storage of rocks in the dump. This will save some money for the generation and disposal of waste (from 1 ton of low-hazardous nontoxic mining waste the fee is $0.5 \mathrm{UAH}$ ), that is, when the generation of waste is 0.5 million tons a year, the savings can reach 0.25 million UAH. In addition, after the operation of iron ore reserves for 30 years, the dump will be liquidated and 15 hectares will be returned to agricultural use, and the need to rehabilitate the waste dump will be eliminated.

In the case of the waste dump removal before the enterprise shutdown date the volume of rocks coming from the drifting faces will be immediately used as part of the backfill mixture without its storage on the surface.

\section{CONCLUSIONS}

The mineralogical and chemical composition of dump rocks has been studied. It is established that the predominant minerals in the rocks are hematite, biotite, chlorite, muscovite, sericite, as well as minerals of the hydromica class. In terms of physicochemical properties, the discovered minerals of dump rocks are inert, do not have astringent properties and form a rigid base in the hardened backfill, absorbing heat during hydration of the binding material. Valuable content of hematite in the composition of waste rocks draws attention to itself as a valuable mineral resource, the extraction of which can be of important commercial importance. 
The addition of rock to the backfill has become a progressive step in the technological, economic and environmental aspects of iron ore mining. This article considers possible ways to increase the volume of rocks due to special preparation of one of the components, hardening backfill and the balance of inflow and utilization in the backfill of waste dumps depending on the content of mine rocks in the inert filler of the backfill mixture is analytically determined.

It is established that at the recommended level of utilization of rocks in the filler, $50 \%$ of the time of the dump removal will take 32 years, and taking into account the service life of the mine being about 30 years, then the waste dump will be completely removed before the enterprise shutdown. If the content of the rock is brought to $60 \%$ - the removal time will make 16.5 years. When using $50 \%$ of rocks in the inert filler of the backfill mixture, the amount of dust formed during storage in the dump will be reduced by $50 \%$, and 15 hectares will be returned to agricultural use, and the need for reclamation of the waste dump is eliminated.

\section{SUMMARY}

The article is devoted to topical issues of increasing the volume of utilization of mine rocks in backfill mixtures on the basis of improving their properties and component composition to improve technological features and environmental consequences. Infrared spectroscopy and scanning electron microscopy were used to determine the mineralogical and chemical composition of dump rocks. An experimental program has been drawn up for a complex of laboratory studies of the properties of filling mixtures of traditional composition and with an increased content of mine rocks under the influence of a finely dispersed binder. A detailed analysis of the waste dump passport has been carried out. The properties of filling mixtures with the content of dump rocks in a combined inert aggregate of $25-50 \%$ have been prepared and determined. The rational interval for adding dump rocks to the inert filler has been determined. The relationship between the time of parsing the waste dump and the amount of rock in the inert aggregate of the filling mixture has been established.

\section{REFERENCES}

1. Hrinov, V.H., Khorolskyi, A.O.., \& Kaliushhenko, O.P. (2019). Elaboration of environmental scenarios for the effective development of valuable mineral deposits. Mineral resources of Ukraine, (2), 46-50. https://doi.org/10.31996/mru.2019.2.46-5 
2. Pavlychenko, A., Buchavyy, Y., Fedotov, V., \& Rudchenko, A. (2017). Development of methodological approaches to environmental evaluation of the influence of manmade massifs on the environmental objects. Technology Audit and Production Reserves,4(3(36)), 22-26. URL: https://doi.org/10.15587/2312-8372.2017.109243.

3. Popovych, V., Kuzmenko, O., Voloshchyshyn, A., \& Petlovanyi, M. (2018). Influence of man-made edaphotopes of the spoil heap on biota. E3S Web of Conferences, (60), 00010. https://doi.org/10.1051/e3sconf/ 20186000010.

4. Pinder, V.F., \& Popovych, V.V. (2017). Reclamation of mine rock dumps of liquidates mines in Lviv-Volyn coal basin. Scientific Bulletin of UNFU, 27(3), 113-116. URL: https://doi.org/10.15421/40270325.

5. Статистичний збірник «Довкілля України» за 2018 рік. (2019). Київ, Україна: Державна служба статистики України, 214 с.

6. Petlovanyi, M., Kuzmenko, O., Lozynskyi, V., Popovych, V., \& Sai, K. (2019). Review of man-made mineral formations accumulation and prospects of their developing in mining industrial regions in Ukraine. Mining of Mineral Deposits, 13(1), 24-38. URL: https://doi.org/10.33271/ mining13.01.024.

7. Chistyakov, E., Ruskih, V., \& Zubko, S. (2012). Investigation of the geomechanical processes while mining thick ore deposits by room systems with backfill of worked-out area. Geomechanical Processes During Underground Mining - Proceedings of the School of Underground Mining, 127-132. https://doi.org/10.1201/b13157-23.

8. Кузьменко, А.М., \& Петлёваный, М.В. (2014). Влияние структуры горного массива и порядка отработки камерных запасов на разубоживание руды. Геотехнічна механіка, (118), 37-45.

9. Kuzmenko, O.M., \& Petlovanyj, M.V. (2017). Steadiness of artificial massif during underground mining of thick ore deposit on a deep depth. Collection of Research Papers of National Mining University, (50), $56-62$.

10. Khorolskyi, A., Hrinov, V., \& Kaliushenko, O. (2019). Network models for searching for optimal economic and environmental strategies for field development. Procedia Environmental Science, Engineering and Management, 6(3), 463-471.

11. Wu, J., Feng, M., Mao, KH., KHu, J., Zhang, W., Ni, KH., \& Han, G. (2018). Particle size distribution of aggregate effects on mechanical and structural properties of cemented rockfill: Experiments and modeling. Construction and Building Materials, (193), 295-311 URL: https://doi.org/10.1016/j.conbuildmat.2018.10.208. 
12. Lingga, B.A., \& Apel, D.B. (2018). Shear properties of cemented rockfills. Journal of Rock Mechanics and Geotechnical Engineering, 10(4), 635-644. https://doi.org/10.1016/j.jrmge.2018.03.005.

13. Мельник, П.Е. \& Хрисанов В.В. (2010). Использование шахтных пород и отходов углеобогащения в качестве закладочного материала при подземной угледобыче. Горный ИнформаџионноАналитический Бюллетень, (5), 282-287.

14. Крупник, Л.А., Битимбаев, М.Ж., Шапошник, С.Н, Шапошник, Ю.Н, \& Демин, В.Ф. (2015). Обоснование рациональной технологии закладочных работ на месторождении Секисовское. Физико-Технические Проблемы Разработки Полезных Ископаемых, (3), 82-90.

15. Bazaluk, O., Petlovanyi, M., Lozynskyi, V., Zubko, S., Sai, K., \& Saik, P. (2021). Sustainable underground iron ore mining in Ukraine with backfilling worked-out area. Sustainability, 13(2), 834. URL: https://doi.org/10.3390/su13020834.

16. Khomenko, O., Kononenko, M., Myronova, I., \& Yurchenko, K. (2017). Ways of technogenic loading decreasing on mining regions of Ukraine. Collection of Research Papers of National Mining University, (51), 77-83.

17. Кузьменко, А.М., \& Петлёваный, М.В. (2014). Состояние и перспективы развития закладочных работ на подземных рудниках Украины. Геотехнічна механіка, (110), 89-97.

18. Накамото, К. (1991). ИК спектры соединений. Москва : Мир, $536 \mathrm{c}$.

19. Голдстейн, Д., Ньюбери, Д., \& Эчлин, П. (1984). Растровая электронная микроскопия bl рентгеновский микроанализ. Москва : Мир, 303 с.

20. Petlovanyi, M.V., Zubko, S.A., Popovych, V.V., \& Sai, K.S. (2020). Physico-chemical mechanism of structure formation and strengthening in the backfill massif when filling underground cavities. Voprosy Khimii $i$ Khimicheskoi Technologii, (6), 142-150. URL: https://doi.org/10.32434/0321-4095-2020-133-6-142-150.

21. Petlovanyi, M., \& Mamaikin, O. (2019). Assessment of an expediency of binder material mechanical activation in cemented rockfill. ARPN Journal of Engineering and Applied Sciences, 14(20), 3492-3503.

22. Кузьменко, А.М., Петлёваный, М.В., \& Усатый, В.Ю. (2010). Влияние тонкоизмельченных фракций шлака на прочностные свойства твердеющей закладки. В Матеріалах Міжнародної науково-практичної конференції “Школа підземної розробки” 
(c. 383-386). Дніпропетровськ, Україна: Національний гірничий університет.

23. Кузьменко, А.М., Петлёваный, М.В., \& Усатый, В.Ю. (2010). Твердеющая закладка при отработке рудных крутых залежей в сложных горно-геологических условиях. Днепропетровск : Национальный горный университет, 139 с.

\section{Information about the authors: \\ Petlovanyi Mykhailo Volodymyrovych,}

Candidate of Technical Sciences, Associate Professor, Associate Professor at the Department of Mining Engineering and Education

Dnipro University of Technology

19, Yavornytskoho avenue, 49005, Dnipro, Ukraine

Ganushevych Kostiantyn Anatoliiovych,

Candidate of Technical Sciences, Associate Professor at the Department of Mining Engineering and Education

Dnipro University of Technology

19, Yavornytskoho avenue, 49005, Dnipro, Ukraine 